Navigation will continue improving all along the river as the slope is adjusted and bars disappear, and if there should be any crevasses, they will be closed.

Early in January of last year, the weather bureau began to send out warnings of coming high water. Hurried preparations were made in the various river districts by the United States and State boards of engineers, for much levee work had been undertaken. New Orleans, with its entire river front absolutely protected against the highest possible water, and with protection levees on all sides, was not in the least danger; but the city was full of Carnival visitors, and the $\mathrm{nat}$ ive s feared the moral effect of a crevasse far more than the pecuniary loss, which they knew must be comparatively small. But during the night of February 21,1907 , the news reached the city that the levee at Live Oak planta. tion, a b o u t twenty-five miles down the river, had given away suddenly. So small an agency as a muskrat hole had done the work. The river, the work. The river, thcn showing 19 feet 8 inches on the weather bureau gage at New Orleans, or about 10 feet above the country at Live Oak plantation, poured th rough the break with a mighty sush. A watchman had passed the spot but a few hours before, but the muskrat ho.l e underfoot

was being steadily washed out, and within four hours after the levee gave way, the crevasse was fully 50 feet wide. Desperate efforts were made to hold the ends with cribbing, built outstream to break the force of the current on the broken levee, but to no purpose. The spot was at the end of a long reach in the river, where the current came with all the impetus of about five miles of straight headway. After several days of fruitless work, the crevasse was abandoned, and the water spread over a vast region, reaching as far up country as Algiers, opposite New Orleans, and over to the Gulf, where much damage was done to the extensive oyster beds of the State.

Then came the consoling forecast of the weather bureau, predicting that by March 5 the river would temporarily fall to a 16-foot level at New Orleans. The weather bureau had never yet missed a forecast on the river, and the news acted as a wonderful stimulant. Mr. Wilkinson was importuned to undertake the task of closing the break. He finally agreed, after obtaining the authority of the levee board in whose district $t \mathrm{he}$ break had occurred, and preparations were made to begin the work when the river would be down at the lowest and most advantageous stage, to which it was rapidly falling.

It was found that the break had by then at. tained a width of 250 feet. Even at the lowered stage, the river was still some 6 or 7 feet higher than the country, and there were $\mathrm{channels}$ washed through the crevasse from 12 to 19 feet deep. Never in the history of the river had such a torrent been turned as that which poured through here, but Mr. Wilkinson, assisted by Colonel Sidney J. Lewis of the State board of engineers of Louisiana, and Superin-

tendent J. S. Landry of the New Orleans, Fort Jackson \& Ship Island Railroad, commenced the work on March 6 , with the river at 5 feet 1 inch.

In the absence of batture, it was found necessary to build the cribbing, or framework destined to hold sacks of earth against the current, on the inner or land side of the broken levee, the depth in river, a short distance beyond the break, being as much as 75 feet. On lines furnished by the engineers, a structure in the form of a bridge, with four rows of light piling, was begun in a semicircle, both ends resting on the levee, on each side of the break, and the crib-

So far, the proceedings presented nothing novel, but it was the method of driving the piles, and the bracing given them against the swift current, which alone made the closing of the break possible. In order to obviate the difficulty of driving piles symmetrically so that they might be solidly attached to each other Mr. Wilkinson conceived the idea of building four pile drivers, connected with each other, and with bing curving landward, so as to form a crescent, 700 feet in length.

places, the employment of trams had been out of the question, and all of the material had to be carried $\mathrm{Ly}$ laborers on their shoulders.

Another interesting detail is that it took some 60,000 sacks of earth to fill the finished cribbing, showing how necessary were the tramway and mule-drawn sars. Fully 20,000 sacks had to be replaced, that quantity having been found so defective that the rushing water washed the sandy earth out of them before they could get fairly settled on the bottom.

When the cribbing was finished, large quantities of rice straw were dropped in front of the break from a barge outstream, and this proved very serviceable in assisting the sacking to seal up the break.

All of this being finished, a row of sheet piling, making a waterproof fence, was driven immediately in front of the cribbing, and the water was completely shut out of the Live Oak plantation and adjacent country by March 17, the whole work being done in eleven days. On March 21, when the work was formally accepted by the Lafourche Basin Levee Board and Mr. Wilkinson was presented with a gold medal, in recognition of $h$ is timely services, there was not a trace of flood water anywhere behind the closed crevasse, and the

Bow View of the Whalebacks After They Had Been Cut.

hammers moved by hand-drawn ropes. By this means, four piles were suspended at the same time, let go fastened into the bottom before the current could have swerved them, a work which would have been well-nigh impossible by any other means. Once driven into the ground, the outer pile was braced by means in the ground the outer pile was braced ened together at one end with a bolt. The bolted pieces were pushed into the water along one pile, the bolted end down, the center piece fastened to the top of the pile, whose lower end was embraced by the projecting ends of the two side pieces, and these side pieces bent out to the top of the pile in the next row, to which they were securely spiked.

This method, used for the first time in crevasse work, assured success. On several occasions enormous drift logs floated in through the break and struck the cribbing with great force; but the bracing proved

planter and the farmer were again working their fields.

\section{SENDING THE WHALEBACKS OUT TO SEA.} BT L. E. Moss.

The Empire Shipbuilding Company, of Buffalo, recently had the contract for preparing three whalebacks-a steamer and two barges-for the trip through the Welland Canal.

The vessels, which had been bought by a Boston firm for the seacoast coal carrying trade, were sent down to Buffalo from the upper lakes. They were tied up in Buffalo and the work of cutting the vessels in two was begun. The photographs show the whalebacks after they were ready. The vessels measured 285 feet in length; and it was found that eighteen feet would have to be cut from each to make it short enough to pass through the Canadian waterway. It was no haphazard job. The forepart of each whalesimultaneously with the weight of the hammers, and back was carefully removed and the sections carefully numbered. Then the pieces were stored in the after hold. The odd appearance of the ships, as thus cut down, attracted no little attention, for the pilot houses projected over the bulkheads at which the hulls were cut in two.

The three ships, the "Bombay," the "Bay City," and the "Baron," as thus shortened, left Buffalo, passed Port Colborne and down Lake Ontario and the St. 'Lawrence to the shipyards at Levis, opposite Quebec. Here they were docked again, and the hull sections that had been removed were taken from the hold and rebuilt in place. Thence the ships sailed out through the gulf and down to their destination at Boston. The whaleback, about eighteen years ago, was heralded as a revolutionizer in lake SENDING THE WHALEBACKS OUT TO SEA

to be so strong that, although a few of the piles were broken, the main part of the cribbing remaine intact and the damage could easily and quickly be repaired.

Another entirely new feature in the closing of this crevasse was the employment of a tramway for the distribution of material, and especially for the carrying of the heavy sacks of earth, which were filled with the material of the top of the existing levee, the only available dry earth. Owing to the lack of solidity of cribbings constructed on previous occasions at other freight traffic. It was in 1891 that the first one crossed the ocean. That was the "Charles W. Whetmore" of 3,000 tons. It was at first thought that they would prove to be excellent vessels for carrying ore and other heavy freight. But the quarters for the crew are uncomfortable, and uncomfortable also is the motion of a whaleback, for it rolls like a $\log$ in heavy weather. The great lake steamers that are now plying the upper waters, of enormous capacities and economical to operate, have done much to crowd out the whaleback. Hence there are few 
of these odd craft to be seen in these days, and those that remain are gradually being transferred to the seacoast, where they can be used for short runs, mostly in the coasting coal traffic.

\section{THE EFFICIENCY OF THE HUMAN MACHINE.}

$$
\text { BY RENÉ BACHE. }
$$

When, not long ago, it occurred to Profs. Atwate and Rosa, of Wesleyan University, to test the efficiency of the human machine-that is to say, the human body, considered as an engine-through the medium of a stationary bicycle rider, it seemed necessary that, in order to obtain exact results, the man and his wheel should be placed inside of a huge box, specially constructed for such purposes, and kept there night and day for a considerable time, measuring mean while all of the food and drink supplied, and even, as one small detail, analyzing the air expired by the subject of the experiment in breathing. The man was mounted on a bicycle, which was fastened to the floor of the box, the front wheel being removed, w hile the rear wheel was so adjustcd that its rim passed between two el ectromagnets. IInas much as the machine, with its rider, its rider, was elevated a few inches a bove the floor, no lo comotion was accomplished, of course, the perf orman ce b e in $g$ merely meant to coun terfeit ordinary bicycle exercise. Thanks to the abovementioned contrivance, $[\mathrm{th}$ e magnets being connected with a dynamo, the a dynamo, the ed was transformed in to electricity, and in that shape measured.

The bor was lined with met al and, in addition, with a network of wires, through the medium of which it was practicable for an expert observer, seated outside at a desk to regudesk, to reguhelp of apparatus specially arranged for the purpose the $t$ e m per ature and degree of mois ture of the air inside. $\mathrm{F} \mathrm{u}$ thermore, the interior was il -

luminated by electricity, so as to render the prison of the solitary rider as cheerful as possible under the circumstances. The power which he himself generated ran one incandescent lamp attached to his machine.

$\mathrm{By}$ an ingenious method of ventilation, the box was kept continually supplied with fresh air, while the used air was drawn out of it, and made to pas through silver cylinders containing lumps of soda iime. The soda lime absorbed all of the carbonic acid that came from the rider's lungs, which was afterward separated out and measured. As already stated, all foods and drink were carefully weighed, and, with tables at hand showing just how much energy is contained in a pound of beefsteak, a poun of eggs, a pound of potatoes, and so on, it was a simple matter to calculate the amount of utilizable fuel that went into the man.

ln other words, it was readily ascertained just how much power went into the human machine in the shape of food consumed. The power that came out, represented by the energy developed, was converted into electricity and measured by a dynamometer- As a result, it was found that the rider actually delivered 21 per cent of the energy contained in the fuel supplied-a very remarkable showing, when it is considered that an economical steam engine delivers in actual horse-power only about 13 per cent of the total heat value of the fuel expended!

It must be considered, however, that a good deal of energy was necessarily utilized by the rider in keeping his own internal mechanism in operation. There was his heart pump, which had to do its regular work; the processes of digestion drew, of course, upon the fuel supply, and so likewise with other functions of the body. In all likelihood, according to Prof. Atwater, an additional 20 per cent of energy was expended in this way. But taking into consideration

the first twenty-four hours, did work that was equiva lent to lifting twenty million pounds one foot-or, to state it otherwise, what was equal to lifting 3,825 pounds (nearly two tons) to a height of one mile. An ordinary laborer, doing average toil, develops that length of time an amount of energy suftcient raise two million pounds one foot. Whence it appears that this human machine, who led in the bicycle contest, delivered as much power as ten such laborers put together.

This may be regarded as representing the utmost possible achievement of the human engine. Onefourth of the total energy. developed, according to Prof Atwater, was expended in overcoming the resistance of the air through which the rider passed. Crouching in a semi-upright posture, he exposed just about three square feet of surface to the opposing atmosphere, and during the first twenty-four hours he was obliged to overcome an air-resistance equal to $5,000,000$ foot-
pounds - in other words to exert as much power as would be required $t o$ lift half a ton to a height of one mile.

Two thou sand a n seven miles were covered by the winner of the race in six days and $s$ i $x$ nights, during which period he los only four pounds i n weight. This loss doubtless $r$ e pre sented body tissue which wa turned to ac count as fuel aving the disestive system ust that much vork. One fact ) a r ticularly loticed, by the vay, was that ; h e f o o d s which agreed jest with the nen who took jart in the ontest wer not the typ aal fuel foods, such as starch, bu t food which furnish ed large persentages of the stuff that goes ordinarily $t$ $\mathrm{n}$ a ke muscle ind blood. Un ler these pe suliar circum st a $\mathrm{n}$ ces the "protein" was burned in the body as fuel, supplying energy.

I t appears then, that the human bod $\mathbf{y}$ runs with less THE EFFICIENCY OF THE HOMAN MACHINE.

merely the energy developed through the bicycle, the experiment gave convincing proof that a man is a more efficient machine than any engine yet devisedthat he will yield more power, for a given amoun of fuel, than the best steam engine or oil engine.

An athlete, says Prof. Atwater, may be regarded as a human machine of exceptional efficiency. Such an individual, engaged in a prolonged contest like a walking match, will deliver 36 per cent of the energy contained in the food he consumes, or sometimes even more Conclusions on this subject were reached through systematic observations of a six-day bicycle race, the experts engaged in the study being present from the beginning to the end of the struggle, by turns night and day, and weighing every morsel of food given to the riders. All of the food was liquid or semi-liquid, and samples were analyzed.

It was estimated that the winner of this race, in waste than any other engine. No other machine is nearly so economical, or will continue in operation for so long a time without wearing out, with so small an expenditure for repairs. The human machine will outlast five of the most improved locomotives; it will keep in running order three times as long as a firstclass printing press, and its "life" is twelve times as long as that of the newest type of automobile. For a given amount of fuel, it yields twice the work of a locomotive engine. In short, it stands to-day unap-

$$
\text { Tire Filler. }
$$

A preparation particularly suitable for filling pneilmatic tires so as to make them puncture-proof, or for molding, [is obtained by heating together 1 pound of glue, 1 pound of molasses, 4 fluid ounces of glycerine, and $1 / 2$ teaspoonful of tar. 